\title{
Life Cycle-Based Generic Business Strategies for Sustainable Business Models
}

\author{
Yoon-Young Chun $^{1} \&$ Kun-Mo Lee ${ }^{1}$ \\ ${ }^{1}$ Eco-Product Research Institute, Department of Environmental Engineering, Ajou University, Suwon, Republic \\ of Korea
}

Correspondence: Kun-Mo Lee, Eco-product Research Institute, Department of Environmental Engineering, Ajou University, San 5, Woncheon-dong, Yeongtong-gu, Suwon 443-749, Republic of Korea. Tel: 82-31-219-2405

E-mail: kunlee@ajou.ac.kr

Received: May 2, 2013 Accepted: July 8, 2013 Online Published: July 16, 2013

doi:10.5539/jsd.v6n8p1 URL: http://dx.doi.org/10.5539/jsd.v6n8p1

\begin{abstract}
The need to transition to a more sustainable economy is one of the most significant challenges society has ever faced. Despite the evidence that adopting a more sustainable business model is linked to more stable profits, many conventional manufacturers do not know where to begin. This study aims to identify generic business strategies that conventional manufacturers can use to improve their business models and thus be more sustainable and/or develop new sustainable business models. In order to identify such strategies, data were gathered from 105 Korean business cases involving a wide range of products and services via online searches and interviews. Business cases were chosen based on whether they relied on a new business paradigm and directly or indirectly generated economic, social, and environmental benefits. Through analyses of the data, generic business strategies were extracted for each life cycle stage. The results showed that the success of a sustainable business model depends on a mixture of pertinent generic business strategies from the life cycle perspective. A conventional business model that focused on a particular life cycle stage and strategy was not very successful. However, a new business model using generic business strategies (such as eco-design as well as product-service system (PSS)-oriented strategies geared at the relevant life cycle stage) produced significant environmental, economic, and social performance improvements. Not only an appropriate mixture of generic business strategies but also systematic support such as infrastructural support is required if manufacturers are to achieve the potential sustainability of a new company-specific business model.
\end{abstract}

Keywords: business strategies, sustainable business model, product-service system (PSS), servicizing, rental, water purifier

\section{Introduction}

With growing concerns about global warming and expanding natural resources, transitioning to a more sustainable economy is one of the most significant challenges society has ever faced. A sustainable economy requires business models that are environmentally, socially, and economically sustainable (Dyllick \& Hockerts, 2002; Elkington, 1997); they must help companies not only achieve fundamental reductions in energy, material, and water use in their activities but also obtain financial and social benefits while providing the necessary products or services (US Environmental Protection Agency [EPA], 2009).

A sustainable business model for a more sustainable economy can be defined as a new business paradigm that generates profit by providing customers with integrated solutions of products and services that directly or indirectly reduce the environmental load while generating profits equal to or greater than those of a conventional business model (Brezet et al., 2001; Mont \& Plepys, 2004; Zaring et al., 2001). Here, a conventional business model refers to a traditional manufacturing model based mainly on sales of goods. The notion of "profit" comprises not only financial gains but also social benefits such as increased employment or job creation. By changing the focus of their business models from manufacturing and sales to providing services, in what is often called "servicizing", companies can exploit the consequent reduction in material/energy use as a strategic means of providing customers with both environmentally and financially improved bottom lines. For example, Xerox changed its business model by replacing its products with services that actually help customers reduce their demand for printers, copiers, paper, and toner, thereby creating environmental benefits as well as increasing its 
market share (Rothenberg, 2004, 2007). Another example is that of Pittsburgh Plate Glass Industries (PPG), which sells automotive paint (Rothenberg, 2004, 2007). It has profitably shifted its business model from selling paint to providing painting services to its client, Chrysler. When Chrysler requested reduced paint use because of high costs and environmental regulations, PPG's strategic response was to help its client reduce its paint use (Rothenberg, 2004, 2007). In addition, PPG took over new management tasks at the plant, including material ordering, inventory tracking, and inventory maintenance related to the painting (Rothenberg, 2004, 2007). Despite the evidence that a strategic orientation toward a more sustainable business model is linked to higher and more stable profits, many conventional manufacturers do not know where to begin. A good way to start would be identifying generic business strategies that can be used to develop a successful sustainable business model.

It is important to clarify why generic business strategies rather than generic business models are a good starting point for conventional manufacturers. Definitions of "business model" and "strategy" as well as notions about their inter-relationship vary among authors, as Seddon and Lewis (2003) have pointed out. However, it is clear that a competitive strategy is a prerequisite to the business model and plays a significant role in its success (Magretta, 2002). Depending upon the business strategies employed, companies can increase their market positions within their current business model or change to a new one (Yip, 2004). Thus, this paper focuses on defining generic business strategies that can be used to improve a business model and/or develop a new, sustainable one.

\section{Literature Review}

The past two decades have seen increased interest in strategies for business sustainability in both academia and the business sector (e.g., Kondoh et al., 2006; Lovins et al., 1999; Reinhardt, 1999). Ever since the concept of product-service system (PSS) was introduced in the early 1990s, many authors (e.g., Lovins et al., 1999; Manzini et al., 2001; Reinhardt, 1999) have viewed PSS as an innovative strategy with the potential to achieve sustainability. Furthermore, PSS' capacity to enhance competitiveness and sustainability has led to massive research efforts (Goedkoop et al., 1999; Halme et al., 2004; Kondoh et al., 2006; Mont, 2000; US EPA, 2009; van Halen et al., 2005) through programs in the EU as well as at national and other levels of government (Tukker \& Tischner, 2006a).

It is generally agreed (Manzini \& Vezzoli, 2003; Tukker, 2004; Tukker \& Tischner, 2006a), however, that PSSs are not always a win-win strategy for both business and the environment. Manzini and Vezzolli (2003) stated that PSS does not necessarily lead to sustainable solutions because of the possibility of rebound effects. Tukker (2004) pointed out that certain types of PSS can be sustainable only if they generate less material flow and fewer emissions while providing incentives for sustainable behavior. Thus, PSS strategies are not a panacea (Tukker, 2004; Tukker \& Tischner, 2006a) and need to be backed up by substantial policy and systematic support to realize their potential to achieve sustainability (Tukker, 2004).

Studies have analyzed sustainable business cases, including examples of PSS (e.g., Bartolomeo et al., 2003; Behrendt et al., 2003; Goedkoop et al., 1999; Kondoh et al., 2006; Mont, 2000; Nakamura et al., 2011; Umeda et al., 2008; US EPA, 2009), but these studies' ultimate goal was to understand sustainable business success, of which there has been little; moreover, sustainable business principles have been rarely applied (Mont, 2000, 2002). One reason for this is that the generic business strategies and conditions required for sustainable business have not been clearly spelled out (Kondoh et al., 2006). To this end, Kondoh et al. (2006) and Umeda et al. (2008) derived the success factors of sustainable businesses in the form of two sets of rules-eight rules for increasing profit and eight rules for reducing the costs of the sustainable business provider-after analyzing 130 business cases in Japan. Furthermore, Nakamura et al. (2011) and Umeda et al. (2008) developed a prototype system by which a business designer may generate ideas and determine the core concepts of sustainable business based on the extracted rules. However, the issue of sustainable business design in the context of the product/service life cycle has not yet been addressed.

Furthermore, very little is known about strategies from a life cycle perspective. Mont (2002) stressed the importance of life cycle-based approaches for a company developing strategies using PSS, illustrating several PSS cases (Mont, 2000) in which the derived strategies were partially matched with various product life cycle stages. Clearly, no company has yet developed a strategy that completely combines a product with a service based on the product life cycle. In short, generic business strategies from the product life cycle point of view are necessary in order to achieve a successful sustainable business.

A systematic approach based on the product life cycle provides companies with a competitive advantage by allocating resources more efficiently where they are most needed (Mont, 2000). Motivated by companies' need for a systematic approach to developing a business model based on the product life cycle and by PSS's 
inadequacy as a perfect solution, this paper seeks to identify the generic business strategies corresponding to each life cycle stage of a product and service in order to create a sustainable business model. These strategies can be used to help conventional manufacturers make their business model more sustainable and/or develop a new, sustainable one.

\section{Methods}

The method of this study is conceptually similar to the procedure used in previous studies (e.g., Kohdoh et al., 2006; Nakamura et al., 2011; Umeda et al., 2008), as it sought to develop guidelines for the success of eco-businesses by collecting existing cases and extracting general rules and conditions from them. Since business strategies are considered the chief elements of a sustainable business model, identifying the business strategies used in successful business cases was the starting point of this study. Though business cases vary by product and service type, this study assumed that different business models might have common business strategies. The generic business strategies identified in this study are widely used and are among those with the potential to generate environmental, economic, or social benefits through successful sustainable business models determined using the three steps described below.

\subsection{Step 1: Collecting and Investigating Successful Sustainable Business Cases}

First, this study collected 105 Korean business cases via online searches and interviews. The target business sectors were not narrowly limited. As shown in Table 1, however, the criterion for selecting business cases was based on the aforementioned definition of a sustainable business model: the business had to rely on a new business paradigm and had to directly or indirectly generate economic, social, and environmental benefits.

Table 1. Criteria for selecting cases of successful sustainable business models

\begin{tabular}{ll}
\hline \multicolumn{1}{c}{ Criteria } & \multicolumn{1}{c}{ Specific criteria } \\
\hline $\begin{array}{l}\text { New business } \\
\text { paradigm }\end{array}$ & $\square$ servicizing only, \\
& $\square$ manufacturing and servicizing at the same time, \\
& $\square$ or manufacturing and selling eco-products \\
\hline Economic benefit & $\square$ increased annual sales, \\
& $\square$ increased market share, \\
& $\square$ and/ or expanding its business to include other product and/or service lines \\
\hline Social benefit & $\square$ increased employment, \\
& $\square$ new job creation, \\
& $\square$ and/or distribution (sharing) of resources \\
\hline Environmental & $\square$ GHG emissions reduction from energy and/or resource consumption, \\
benefit & $\square$ increased recycling/reuse rate, \\
& $\square$ eco-design technology development, \\
& $\square$ and/ or environmental communications (e.g., eco-labels) \\
\hline
\end{tabular}

\subsection{Step 2: Extracting Business Strategies From Each Case Based on the Nine Life Cycle Stages}

Second, business strategies corresponding to the product life cycle stages were extracted from each business case. For example, in the case of the office furniture leasing business, a strategy named "recycling of materials" can be extracted from the end-of-life stage and a strategy named "providing maintenance service" from the use stage. Here, the criterion for extracting a business strategy from a given business case was whether the strategy had the potential to generate a positive effect on environmental, economic, or social performance.

To effectively and systematically extract the business strategies from the business cases, the relevant product life cycle stages were defined. Normally, a product life cycle is defined as a process of resource transformation in five distinctive stages: the use of raw materials, manufacture, distribution, product use, and end of life. However, in the context of sustainable business, service cycles or other business activities occur between and within the five product life cycle stages. For example, an installation may occur between the distribution and product use 
stages, while maintenance or management services such as checking and repair are necessary in the product use stage.

Therefore, this study amalgamated the five stages of the product life cycle and reclassified them into nine stages, including service cycles. The nine life cycle stages defined were design, production, distribution, sales, installation, use (including maintenance), collection, remanufacturing, and waste management. Each life cycle stage was further broken down into sub-stages (if applicable) and given an identification number from 1 to 9 , where LC-1 corresponds to design, LC-2 to production, LC-3 to distribution, and so on., as shown in Table 2.

Table 2. Nine life cycle stages defined for extracting business strategies

\begin{tabular}{llll}
\hline \multicolumn{1}{c}{ Identification No. } & Nine life cycle stage & \multicolumn{1}{c}{ Sub-stage } \\
\hline LC-1 & \multicolumn{1}{c}{ Design } \\
\hline LC-2 & & Production & \\
\hline LC-3 & LC-3-1 & Distribution & Packaging \\
& LC-3-2 & Storage \\
& LC-3-3 & Delivery \\
\hline LC-4 & LC-4-1 & Sales & Ultimate sales \\
& LC-4-2 & & Non-ultimate sales \\
\hline LC-5 & & Installation & \\
\hline LC-6 & LC-6-1 & Use and maintenance & Pay-per-use \\
& LC-6-2 & & Pooling \\
& LC-6-3 & Sharing \\
& LC-6-4 & Renting \\
& LC-6-5 & & Leasing \\
& LC-6-6 & & Single use \\
\hline LC-7 & & & \\
\hline LC-8 & LC-8-1 & Collection & Refurbishing \\
& LC-8-2 & Remanufacturing & Upgrading \\
\hline LC-9 & LC-9-1 & Reuse \\
& LC-9-2 & Waste management & Recycling \\
& LC-9-3 & & Recovery \\
\hline
\end{tabular}

All decisions about product and service specification are made in the design stage. According to the specification defined during this stage, the manufacture of parts, sub-assemblies, and components occurs in the production stage. Some life cycle stages, such as distribution, sales, use and maintenance, remanufacturing, and waste management, can be divided into several sub-stages, as shown in Table 2.

The distribution stage encompasses much more than just product delivery. It also includes sub-stages such as packaging and storage. In the sales stage, a producer can take two different actions: selling a product and/or service and transferring ownership to the customers (ultimate sales sub-stage), or, alternatively, performing non-ultimate sales (non-ultimate sales sub-stage), in which the producer sells not a product but a function delivered by a service while retaining ownership.

Depending on the constraints and conditions of the customer's contract with the producer (i.e., the product and/or service provider) in the sales stage, different sub-stages such as pay-per-use, pooling, sharing, renting, and leasing with additional maintenance activities can occur during the use stage. Additionally, single use can appear as a sub-stage of the use stage, although this does not come under the specific contract for providing maintenance services. The remanufacturing stage comprises the refurbishing and upgrading sub-stages, whereas the waste management stage includes sub-stages such as reuse, recycling, and recovery. 


\subsection{Step 3: Identifying Generic Business Strategies in Each Life Cycle Stage}

Business strategies extracted from each business case become candidates for the generic business strategies. In identifying the relevant business strategies within each business case, common business strategies were found for each life cycle stage. Based on these common strategies, generic business strategies for each life cycle stage were determined.

\section{Results}

\subsection{Successful Sustainable Business Cases in Korea}

Sustainable businesses provide their customers with functions delivered in the form of a product and/or service. As shown in Table 3, the collected business cases can be classified by product or service group. The scale of the businesses varies from large to small depending on the size of a company, but most cases have a high market share in their business sector.

Table 3. Classification of the product and service groups for the collected business cases

\begin{tabular}{lclc}
\hline Product/service group & $\begin{array}{c}\text { Number } \\
\text { of cases }\end{array}$ & \multicolumn{1}{c}{ Product/service group } & $\begin{array}{c}\text { Number } \\
\text { of cases }\end{array}$ \\
\hline Office/house equipment and furniture & 9 & Electrical and electronic appliances & 16 \\
$\begin{array}{l}\text { Information and communication } \\
\text { equipment }\end{array}$ & 14 & Machine equipment & 4 \\
Textile, kitchen/household products & 7 & Raw/subsidiary materials, waste & 3 \\
Chemicals, cosmetics, detergent, etc. & 6 & Energy & 3 \\
Vehicles (including automobiles) & 8 & Logistics & 2 \\
Sports, leisure and entertainment & 5 & Food and beverage & 5 \\
Tourism & 2 & Toys, baby and kids products & 2 \\
Safety, security, and sanitation & 7 & Others & 5 \\
Life and welfare & 7 & Total & 105 \\
\hline
\end{tabular}

Several of the business cases rely on the traditional business model-manufacturing and selling. They produce eco-products that have less environmental impact and more potential to encourage consumers to change their behavior or social/cultural perceptions and thus make them use the products more sustainably.

For instance, NHN Corp has developed the Nanum-ecofont, a font that uses tiny circles for its characters, under a technical partnership with Ecofont BV (NHN Corporation, 2011). Without needing to reduce the font size, the Nanum-ecofont can reduce ink and toner consumption because each letter consists of open circles, thus no ink is used. Furthermore, since the font does not appear different when in normal print sizes, users can change their printing behavior without hesitation.

\subsection{Business Strategies Applied in Each Life Cycle Stage}

Extracting the business strategies from the collected business cases reveals that more than one strategy has been applied throughout the life cycle. Table 4 shows an example of business strategies being applied not only in the design stage but also in the other life cycle stages/sub-stages of a water purifier, including ultimate and non-ultimate sales, installation, renting, collection, refurbishing, and recycling. This indicates that there are appropriate business strategies for specific product life cycle stages and/or sub-stages and that a unilateral application of a single business strategy should thus be avoided. Therefore, pursuing business strategies based on the life cycle perspective is critical to the success of a business model. 
Table 4. Business strategies for a water purifier rental business at each life cycle stage

\begin{tabular}{|c|c|}
\hline Life cycle stage & Business strategies applied at each life cycle stage \\
\hline LC-1 & Designing a slim-sized hot water tank and smaller filter to reduce the size of the product \\
\hline LC-4-1 & Selling a refurbished product at a price discounted from $20 \%$ to $50 \%$ \\
\hline LC-4-2 & $\begin{array}{l}\text { Selling a rental service at a lower fee (i.e., lower than the purchase price) over a five-year } \\
\text { contract period }\end{array}$ \\
\hline LC-5 & $\begin{array}{l}\text { A trained expert visits the customers' premises, installs the product, and gives guidance on } \\
\text { its use }\end{array}$ \\
\hline \multirow{3}{*}{ LC-6-4 } & Rental service with additional service \\
\hline & $\begin{array}{l}\text { - Regularly check the condition of the product and give users feedback on the right way } \\
\text { to use it }\end{array}$ \\
\hline & - Repair (A/S) service \\
\hline LC-7 & Take back service (only for service renewal customers) \\
\hline LC-8-1 & $\begin{array}{l}\text { Sorting products in good condition from returns, cleaning, and repackaging for sale at a } \\
\text { bargain price }\end{array}$ \\
\hline \multirow{2}{*}{ LC-9-2 } & Recycling packaging materials \\
\hline & Disassembling the waste products to sell plastics and metals for reutilization \\
\hline
\end{tabular}

Surprisingly, the water purifier rental business started from a conventional manufacturing and sales business model, meaning that the business had employed the simple strategy of selling water purifiers in the sales stage. After the company took a life cycle approach, as shown in Table 4 in 1998, the company shifted its business model and increased its annual sales from 30 billion won (US\$ 30 million) to more than 1.8 trillion won (US\$ 1.8 billion) in 2011. Furthermore, the business has had an outstanding social effect by creating 13,000 Cody positions, filled by trained water purifier management experts who visit customers regularly to ensure that their products are in optimal condition. Since the Cody is responsible for maintenance and encouraging customers to properly use their water purifier, the environmental impact of the product has been reduced due to its extended lifespan and increased efficiency during use stage.

Contrary to the abovementioned example, other business cases have followed the relatively simple strategy of selling products in the sales stage. Nonetheless, they can be readily distinguished from the conventional business paradigm in that they have applied a variety of business strategies at other life cycle stages.

As seen in Table 5, one company that buys and sells second-hand books has maintained the product-sale strategy; in the collection stage, though, the company has contracted with a chain of convenience stores for the delivery of used books from customers. Therefore, customers who want to sell their used books (products) only need to hand them in at the nearest convenience store.

Table 5. Business strategies of a second-hand book reuse business at each life cycle stage

\begin{tabular}{|c|c|}
\hline Life cycle stage & Business strategies applied at each life cycle stage \\
\hline LC-3-2 & $\begin{array}{l}\text { Adopting an online system for buying and selling products so that the company can } \\
\text { improve its logistical operations and consequently save space, energy, and costs }\end{array}$ \\
\hline LC-4-1 & Selling reused products at prices discounted $50 \%$ or more \\
\hline \multirow[t]{2}{*}{ LC-7 } & $\begin{array}{l}\text { - Providing customers with convenient delivery of the books to the book } \\
\text { buyer via a nationwide chain of convenience stores. This saves customers time } \\
\text { and effort, which encourages the first users to hand over their used books to the } \\
\text { second users }\end{array}$ \\
\hline & - $\quad$ Customers can also use authorized courier delivery services \\
\hline LC-8-1 & Cleaning and gluing for use one more time \\
\hline
\end{tabular}


To send their books for sale, customers used to have to find a post office and take the time to go there. In another case, the customer selling the book makes an appointment with a courier service to collect the used book. After the inconveniences that hindered the collection and reuse of the second-hand books were addressed, the company's annual growth rate surged close to $60 \%$ above its rate when the reuse business began.

\subsection{Life Cycle-Based Generic Business Strategies for Sustainable Business Models}

Table 6 shows the relationship between business cases and life cycle stages/sub-stages. Three different business cases -rental of water purifiers, (indoor) flowers and plants, and baby products-have the same business model: rental. Table 6 shows that the three business cases share the same life cycle stages and sub-stages, with very minor differences.

Table 6. Applicable life cycle stages/sub-stages for three different business cases featuring the rental business model

\begin{tabular}{|c|c|c|c|c|c|c|c|c|c|c|c|c|c|c|c|c|c|c|c|c|}
\hline \multirow{3}{*}{$\begin{array}{l}\text { Business } \\
\text { Case }\end{array}$} & \multicolumn{20}{|c|}{ Life cycle stage: ID No. (LC-0-0) } \\
\hline & \multirow{2}{*}{1} & \multirow{2}{*}{2} & \multicolumn{3}{|c|}{3} & \multicolumn{2}{|c|}{4} & \multirow{2}{*}{5} & \multicolumn{6}{|c|}{6} & \multirow{2}{*}{7} & \multicolumn{2}{|c|}{8} & \multicolumn{3}{|c|}{9} \\
\hline & & & $3-1$ & $3-2$ & $3-3$ & $4-1$ & $4-2$ & & $6-1$ & $6-2$ & $6-3$ & $6-4$ & $6-5$ & $6-6$ & & $8-1$ & $8-2$ & $9-1$ & $9-2$ & $9-3$ \\
\hline $\begin{array}{l}\text { Water } \\
\text { purifier } \\
\text { rental }\end{array}$ & $\sqrt{ }$ & & & & & $\sqrt{ }$ & $\sqrt{ }$ & $\sqrt{ }$ & & & & $\sqrt{ }$ & & & $\sqrt{ }$ & $\sqrt{ }$ & & & $\sqrt{ }$ & \\
\hline $\begin{array}{l}\text { Flower } \\
\text { and plant } \\
\text { rental }\end{array}$ & $\sqrt{ }$ & & & & & & $\sqrt{ }$ & $\sqrt{ }$ & & & & $\sqrt{ }$ & & & $\sqrt{ }$ & $\sqrt{ }$ & & $\sqrt{ }$ & $\sqrt{ }$ & \\
\hline $\begin{array}{l}\text { Baby } \\
\text { product } \\
\text { rental }\end{array}$ & $\sqrt{ }$ & & & & & $\sqrt{ }$ & $\sqrt{ }$ & $\sqrt{ }$ & & & & $\sqrt{ }$ & & & $\sqrt{ }$ & $\sqrt{ }$ & & & $\sqrt{ }$ & \\
\hline
\end{tabular}

In the sales stage, both the water purifier and baby product rental businesses had an ultimate sales sub-stage (LC-4-1) in which they sold reutilized (refurbished or reused) products and a non-ultimate sales sub-stage (LC-4-2) in which they provided a rental service. Meanwhile, the flower and plant rental business had only a non-ultimate sales sub-stage (LC-4-2) in which they provided products and management services during the contract period.

In the waste management stage, the flowers and plants rental business had a reuse sub-stage (LC-9-1) in which parts of flowers and plants were reused after the removal of the rotten parts or, if that was impossible, the recycle sub-stage (LC-9-2) occurred, in which the waste products were recycled as fertilizer. On the other hand, the companies renting the water purifier and baby products had only the recycling sub-stage (LC-9-2), for they did not reuse any part of the product but indirectly recycled by extracting and selling the usable and recyclable parts and materials in response to customers' negative reactions to product reuse.

The above observation indicates that the same or similar life cycle stages and sub-stages can coexist in a given business model (here, rental) regardless of the business case; however, this is not so when the cases' business models are different. Business models depend on the product, service, and business type, such as providing only services (i.e., servicizing), both manufacturing and servicizing, or manufacturing only but changing consumers' behavior.

Business strategies were extracted from each business case through an analysis of 105 Korean businesses. Irrespective of the business model, generic business strategies are identifiable at each life cycle stage/sub-stage, as shown in Table 7. 
Table 7. Generic business strategies at each life cycle stage/sub-stage

\begin{tabular}{|c|c|c|c|}
\hline \multicolumn{2}{|c|}{ Stage/sub-stage } & \multicolumn{2}{|c|}{ Generic business strategy } \\
\hline \multirow{3}{*}{ LC-1 } & \multirow{3}{*}{ Design } & \multirow{3}{*}{\multicolumn{2}{|c|}{$\begin{array}{l}\text { - substituting material with information or knowledge } \\
\text { - using fewer materials for a specific function } \\
\text { - reducing the environmental impact associated with the use of materials }\end{array}$}} \\
\hline & & & \\
\hline & & & \\
\hline \multirow{3}{*}{$\mathrm{LC}-2$} & \multirow{3}{*}{ Production } & \multicolumn{2}{|c|}{ - using clean/innovative technologies (e.g., solar energy) } \\
\hline & & \multicolumn{2}{|l|}{ - reducing energy consumption } \\
\hline & & \multicolumn{2}{|l|}{ - reducing waste } \\
\hline LC-3-1 & Packaging & \multicolumn{2}{|l|}{ - increasing the efficiency of material use } \\
\hline LC-3-2 & Storage & \multicolumn{2}{|c|}{ - improving the efficiency of existing operations } \\
\hline LC-3-3 & Delivery & \multicolumn{2}{|c|}{ - improving the efficiency of existing operations } \\
\hline \multirow{3}{*}{ LC-4-1 } & \multirow{3}{*}{ Ultimate sales } & \multirow{2}{*}{$\begin{array}{l}\text { - encouraging customers to purchase } \\
\text { eco-products/services (e.g., } \\
\text { reutilized products) }\end{array}$} & $\begin{array}{l}\text { a. by remarketing and selling a refurbished } \\
\text { product through retail, auction, or } \\
\text { consignment sale }\end{array}$ \\
\hline & & & $\begin{array}{l}\text { b. by advertising and selling an eco-product } \\
\text { (except reutilized products such as } \\
\text { energy-saving products) with additional } \\
\text { services or incentives }\end{array}$ \\
\hline & & \multicolumn{2}{|l|}{ - mass customizing } \\
\hline \multirow{3}{*}{ LC-4-2 } & \multirow{3}{*}{ Non-ultimate sales } & \multirow{3}{*}{$\begin{array}{l}\text { - encouraging customers to abandon } \\
\text { ownership }\end{array}$} & $\begin{array}{l}\text { a. by providing cost savings or tax benefits to } \\
\text { customers }\end{array}$ \\
\hline & & & $\begin{array}{l}\text { b. by promising to offer additional services } \\
\text { such as maintenance and ultimate disposal }\end{array}$ \\
\hline & & & $\begin{array}{l}\text { c. by enabling customers to avoid } \\
\text { environmental risks }\end{array}$ \\
\hline LC-5 & Installation & - giving information about the proper & se of a product/service \\
\hline \multirow{4}{*}{ LC-6 } & \multirow{4}{*}{$\begin{array}{l}\text { Use and } \\
\text { maintenance }\end{array}$} & - increasing material-use intensity & $\begin{array}{l}\text { a. prolong the product's lifetime via regular } \\
\text { maintenance activities such as checks and } \\
\text { repairs }\end{array}$ \\
\hline & & & $\begin{array}{l}\text { b. increasing demand per product/service for } \\
\text { customers }\end{array}$ \\
\hline & & $\begin{array}{l}\text { - (directly) reducing the use of } \\
\text { energy/materials }\end{array}$ & $\begin{array}{l}\text { a. by encouraging users (through information } \\
\text { or feedback) to change their behavior } \\
\text { without much effort }\end{array}$ \\
\hline & & $\begin{array}{l}\text { - (indirectly) reducing the use of } \\
\text { energy/materials }\end{array}$ & $\begin{array}{l}\text { b. by making users pay the electricity, gas, } \\
\text { water and other bills for consumables during } \\
\text { their use }\end{array}$ \\
\hline \multirow{3}{*}{ LC-7 } & \multirow{3}{*}{ Collection } & $\begin{array}{l}\text { - increasing the rate of } \\
\text { self-collection }\end{array}$ & - take-back service \\
\hline & & \multirow{2}{*}{$\begin{array}{l}\text { - encouraging customers to directly } \\
\text { deliver waste to the next stage }\end{array}$} & $\begin{array}{l}\text { - giving customers incentives or cost savings } \\
\text { without much effort }\end{array}$ \\
\hline & & & - solving customer inconvenience problems \\
\hline \multirow[t]{2}{*}{ LC-8 } & \multirow[t]{2}{*}{ Remanufacturing } & $\begin{array}{l}\text { - prolonging product lifetime by } \\
\text { reassembling the product to meet the } \\
\text { original specifications }\end{array}$ & - refurbishing or using one more time \\
\hline & & $\begin{array}{l}\text { - prolonging product lifetime by } \\
\text { adding or replacing functionality }\end{array}$ & - upgrading or improving the performance \\
\hline \multirow{3}{*}{ LC-9 } & \multirow{3}{*}{ End-of-life } & \multirow[b]{2}{*}{ - reutilizing waste directly } & a. reuse of parts in refurbishing \\
\hline & & & $\begin{array}{l}\text { b. recycling materials to reduce virgin } \\
\text { feedstock use in production }\end{array}$ \\
\hline & & - reutilizing waste indirectly & $\begin{array}{l}\text { - extracting and selling useable and } \\
\text { recyclable parts and materials }\end{array}$ \\
\hline
\end{tabular}

\section{Discussion}

Many business cases illustrate that the success of a sustainable business depends not only on PSS-oriented strategies (see, for example, the generic business strategies in LC-4-2 and LC-6 in Table 7) but also on the appropriate application of various solutions at each life cycle stage, such as product eco-design or waste 
reutilization (see, for example, the generic business strategies in LC-1 or LC-9 in Table 7). As previous studies have indicated, PSS is not a stand-alone solution (Mont, 2004; Tukker \& Tischner, 2006b), and conventional manufacturers must bear in mind that there are no new, epoch-making strategies for achieving a sustainable business. Therefore, helping manufacturers generate business strategies for sustainability requires the consideration of a mixture of pertinent business strategies (such as those listed in Table 7), to be pursued throughout the life cycle stages of the product being manufactured, sold, and servicized.

PSS-oriented strategies can be distinguished from other strategies in the sales stage according to who owns the product; this is also the way to distinguish between the ultimate and non-ultimate sales stages. Even when applying a PSS-oriented strategy, which is encouraging customers to abandon ownership in the sales stage, a producer may finally transfer ownership of the product to the customers. Many Korean businesses have used these non-ultimate PSS strategies, which are similar to long-term installment selling but differ in that additional services are offered during the installment period.

In most of the business cases where the producer ultimately transferred product ownership to the customers, the product's purchase price was higher than the demand per customer. In addition, the function delivered by the product and/or service was directly relevant to cleaning, sanitation, or health issues (e.g., water purifier, mattress, kitchen hood, air cleaner, massage chair, bidet). This occurred because users often have negative feelings about shared or second-hand products, especially those related to health, sanitation, or safety; thus, selling the function delivered by the product to the first user was not difficult, but the producer encountered problems when re-selling the function through the same product to subsequent users.

On the other hand, for functions with a brief physical lifetime per customer (e.g., baby furniture, seasonal products such as air-conditioners and heaters), the producer usually only helped customers maintain the function: ownership was not transferred. Therefore, when manufacturers adopt PSS-oriented strategies in their sales stage, they need to consider not only customer demand and the desire to possess their target products but also the characteristics of the products they manufacture, sell, and servicize, such as their physical lifetimes and health or sanitation issues.

Adopting a variety of business strategies using life cycle approaches generally increases opportunities for companies to create environmental, economic, and social benefits because planning and implementing business strategies is meant to achieve the company's business mission, such as reducing resource consumption, minimizing waste, managing financial risk, and maximizing earnings. However, not all business strategies that generate environmental benefits create profit or social benefits and vice versa. Nevertheless, businesses pursuing strategies in which a certain life cycle has a negative economic effect can still be economically viable if the final result is a profit.

For the water purifier rental business example, Table 8 shows the correlation between each business strategy and the environmental, economic, and social effects. For example, in the design stage (LC-1), the eco-design business strategy of reducing the size thus using less material had a strong and direct effect on the environment. On the other hand, the producer had to spend more money to develop a slim-sized water purifier without reducing its filtering capacity. In the use and maintenance stage (LC-6-4), the business strategy for the rental service may not generate economic benefits from the producer's perspective, because it costs more money to regularly operate services using door-to-door servicepersons performing tasks such as checks and repairs.

However, from the life cycle perspective, the business strategy will encourage more consumers to choose the rental service rather than buy the product, thus producing a positive return, creating positive economic effects sufficient to offset the negative effects in the use and maintenance stages. In addition, a consumer (a product/service user) can achieve cost-savings by receiving additional maintenance services, thus enjoying reliable and consistent operation at a lower fee (i.e., lower than the cost of purchasing the water purifier). Moreover, most of the business strategies for the water purifier rental business generate positive environmental effects. Customers' payment of electricity bills for the water purifier as an energy-consuming product reduces the risk that customer behavior will produce negative environmental effects, especially during the use stage.

Therefore, before determining what and how appropriate generic business strategies can be implemented, the correlation between generic business strategies and their economic, environmental, and social effects at each life cycle stage must be taken into account. In addition, the total economic, environmental, and social performance produced by a mixture of strategies over the whole life cycle must also be considered in the correlation. 
Table 8. Correlation between business strategies and environmental, economic, and social effects (for the water purifier rental business case)

\begin{tabular}{|c|c|c|c|c|c|c|}
\hline \multirow{2}{*}{ Stage } & \multirow{2}{*}{$\begin{array}{l}\text { Business strategy for this } \\
\text { case }\end{array}$} & \multirow{2}{*}{$\begin{array}{l}\text { Business strategy in generic } \\
\text { form }\end{array}$} & \multirow{2}{*}{$\begin{array}{c}\text { Environ } \\
\text {-mental } \\
\text { effect }\end{array}$} & \multicolumn{2}{|c|}{$\begin{array}{l}\text { Economic } \\
\text { effect }\end{array}$} & \multirow{2}{*}{$\begin{array}{l}\text { Social } \\
\text { effect }\end{array}$} \\
\hline & & & & $\mathrm{P}$ & $\mathrm{C}$ & \\
\hline LC-1 & $\begin{array}{l}\text { Product design for a } \\
\text { slim-sized filter/water tank }\end{array}$ & $\begin{array}{l}\text { Using fewer materials for a } \\
\text { specific function }\end{array}$ & $++^{*}$ & $+/-$ & $0 /-$ & 0 \\
\hline LC-4-1 & $\begin{array}{l}\text { Selling a refurbished product } \\
\text { at a discounted price }\end{array}$ & $\begin{array}{l}\text { Encouraging customers to } \\
\text { purchase eco-products } \\
\text { (refurbished products) by } \\
\text { selling refurbished products } \\
\text { through retail outlets }\end{array}$ & $+*$ & $+*$ & $++*$ & 0 \\
\hline LC-4-2 & $\begin{array}{l}\text { Selling a rental service at a } \\
\text { lower fee }\end{array}$ & $\begin{array}{l}\text { Encouraging customers to } \\
\text { abandon ownership by } \\
\text { including cost savings on } \\
\text { customers' behalf, a monthly } \\
\text { rental fee for using a highly } \\
\text { expensive product, and } \\
\text { promising to offer additional } \\
\text { maintenance services during } \\
\text { use stage }\end{array}$ & 0 & $++^{*}$ & $+*$ & 0 \\
\hline LC-5 & Installation with consultation & $\begin{array}{l}\text { Increasing the efficiency of } \\
\text { energy use; giving } \\
\text { information about the proper } \\
\text { use of a product/service }\end{array}$ & + & $0 /-$ & + & $+^{*}$ \\
\hline \multirow[t]{2}{*}{ LC-6-4 } & \multirow{2}{*}{$\begin{array}{l}\text { Rental service with } \\
\text { additional services } \\
\text { - Checking the condition of a } \\
\text { product and giving users } \\
\text { feedback on the right way to } \\
\text { use the product } \\
\text { - Repair (A/S) service }\end{array}$} & $\begin{array}{l}\text { Increasing material-use } \\
\text { intensity by regular } \\
\text { maintenance activities }\end{array}$ & $+* /-$ & - & $++*$ & $++^{*}$ \\
\hline & & $\begin{array}{l}\text { Indirectly reducing the use } \\
\text { of energy/materials by } \\
\text { making users pay electricity } \\
\text { and water bills during their } \\
\text { use }\end{array}$ & $++^{*}$ & 0 & $+*$ & 0 \\
\hline LC-7 & $\begin{array}{l}\text { Take-back service (only for } \\
\text { the service renewal } \\
\text { customers) }\end{array}$ & $\begin{array}{l}\text { Increasing the rate of } \\
\text { collection through take-back } \\
\text { service }\end{array}$ & $+*$ & + & + & + \\
\hline LC-8-1 & Refurbishing & $\begin{array}{l}\text { Prolonging the product } \\
\text { lifetime by using one more } \\
\text { time }\end{array}$ & $++^{*}$ & $+/-$ & 0 & + \\
\hline \multirow[t]{2}{*}{ LC-9-2 } & $\begin{array}{l}\text { Recycling packaging } \\
\text { materials }\end{array}$ & $\begin{array}{l}\text { Reutilizing waste directly by } \\
\text { recycling materials }\end{array}$ & $++^{*}$ & $+*$ & 0 & 0 \\
\hline & $\begin{array}{l}\text { Disassembling the waste } \\
\text { products to sell plastics and } \\
\text { metals for reutilization }\end{array}$ & $\begin{array}{l}\text { Reutilizing waste indirectly } \\
\text { by extracting and selling } \\
\text { useable materials }\end{array}$ & ++ & $+*$ & 0 & + \\
\hline
\end{tabular}

$++--:$ very relevant (positive/negative)

+/-: relevant (positive/negative)

0 : indifferent

*: direct effect

P: from the viewpoint of producers, $\mathrm{C}$ : from the viewpoint of consumers 
A mixture of pertinent generic business strategies can play an important role in changing key elements of a business model and therefore transforming a conventional business model into a new one. The key elements of a business model include customers, customer value, profits, and delivering value to customers (Magretta, 2002). Table 9 shows the key elements of both a conventional and a new business model for the water purifier manufacturer discussed above. The business model shift enabled the manufacturer to generate approximately sixty times more sales volume, from US\$30 million in 1998 to US\$1.8 billion in 2011 . All four factors combined contributed to the successful transformation from the conventional to the new business model.

However, the same model cannot be applied unilaterally in all market conditions. The water purifier model was applied in China but failed because customer demand for purified water in the Chinese market differed from that in Korea: as the Chinese prefer to drink tea rather than tap water, demand for purified water was quite low.

Table 9. Key elements of a business model (water purifier business model case)

\begin{tabular}{|c|c|c|}
\hline Key element & Conventional business model & New business model \\
\hline $\begin{array}{l}\text { Applied business } \\
\text { strategies }\end{array}$ & Application of a single business strategies & $\begin{array}{l}\text { with a mixture of pertinent generic } \\
\text { business strategies, as described in Table } 4\end{array}$ \\
\hline Customers & Targeted at housewives or offices & Membership (rental) and regular customers \\
\hline \multirow[t]{2}{*}{ Customer value } & $\begin{array}{l}\text { Product (water purifier) and limited } \\
\text { warranty }\end{array}$ & $\begin{array}{l}\text { - the function of purifying and supplying } \\
\text { water }\end{array}$ \\
\hline & & - regular maintenance services \\
\hline \multirow[t]{3}{*}{$\begin{array}{l}\text { How to make } \\
\text { profits }\end{array}$} & $\begin{array}{l}\text { From overall sales of water purifiers; from } \\
\text { solely manufacturing }\end{array}$ & $\begin{array}{l}\text { - from overall sales of new and refurbished } \\
\text { water purifiers }\end{array}$ \\
\hline & & $\begin{array}{l}\text { - from overall sales of contract; monthly } \\
\text { fees for rental and membership }\end{array}$ \\
\hline & & $\begin{array}{l}\text { - from waste management by selling } \\
\text { useable waste }\end{array}$ \\
\hline $\begin{array}{l}\text { How to deliver } \\
\text { value to } \\
\text { customers }\end{array}$ & $\begin{array}{l}\text { Traditional manufacturing and selling a } \\
\text { product with a limited warranty }\end{array}$ & $\begin{array}{l}\text { By trained management experts who visit } \\
\text { customers regularly }\end{array}$ \\
\hline
\end{tabular}

Systematic support, both internal and external, is often needed to work generic business strategies into a new business model at a specific product life cycle stage and/or sub-stage. External support refers to customer demand, market trends, policy tools, and infrastructural support, whereas internal support comprises human resources and other physical entities, such as technology and facilities. For example, after several failed attempts, a new car-sharing business (Green Car, 2011) has gradually broadened the geographical scope of its activities through external supports such as subsidies and other infrastructural assistance.

As shown in Table 10, policy tools such as subsidies for a car-sharing service and infrastructural supports such as charging stations are examples of external support. However, manufacturers cannot easily control or change their external support, so they must consider internal support instead, especially if they are taking risks by investing money and time, before implementing a new business model. 
Table 10. Components of systematic support (external and internal) for the success of a new business model (car-sharing business model case)

\begin{tabular}{ll}
\hline Systematic support & \multicolumn{1}{c}{ Components } \\
\hline External support & - Customer demand \\
& - Market trends \\
& - Policy tools such as subsidies to a car-sharing service for the purchase of \\
& electric vehicles or chemical management services designed to satisfy \\
& regulations or laws on hazardous chemicals \\
& - Infrastructural support such as charging stations for the electric-car sharing \\
& business, integrated systems for a bike rental business and public \\
& transportation, or car-sharing insurance \\
\hline Internal support & - Human resources such as trained repair experts or other maintenance service \\
& providers \\
& - Technologies such as modular design technologies for remanufacturing \\
& - Facilities such as assembly, disassembly, or shredding facilities for reuse and \\
& recycling \\
& - Spaces such as recycling centers \\
\hline
\end{tabular}

\section{Conclusions}

A total of 105 Korean sustainable business cases were analyzed. For the businesses that directly or indirectly generated economic, social, and environmental effects, the overlapping business strategies at each life cycle stage were extracted so that generic business strategies could be identified. Major findings of this study are the following:

i) There are appropriate business strategies for specific product life cycle stages and/or sub-stages; thus, a unilateral application of a single business strategy should be avoided. Business strategies based on the life cycle perspective are critical to the success of a business model.

ii) The same or similar life cycle stages and sub-stages can coexist in a given business model, regardless of the business case; this is not true, however, when the business models of the cases differ. Business models depend on the product, service, and business type, such as that which provides services only, that which provides both manufacturing and servicizing, or that which only manufactures but also changes consumer behavior.

iii) Irrespective of the business model, there are generic business strategies for each life cycle stage and sub-stage.

iv) The success of a sustainable business model depends not only on PSS-oriented strategies but also on the appropriate application of diverse solutions (e.g., product eco-design or waste reutilization) at each life cycle stage.

v) When manufacturers adopt PSS-oriented strategies at the sales stage, they need to consider not only customer demand or desire to possess their target products but also the characteristics of the products they manufacture, sell, and servicize, such as their physical lifetimes and health and sanitation issues.

vi) The correlation between generic business strategies and their economic, environmental, and social effects at each life cycle stage must be assessed before a determination can be made about what appropriate generic business strategies can be implemented and how. In addition, the total economic, environmental, and social performance produced by a mixture of strategies over the whole life cycle must also be considered in the correlation.

vii) A mixture of pertinent generic business strategies can play an important role in changing key elements of a business model (such as customers, customer value, profit, and value delivery to customers), and therefore, transforming a conventional business model into a new one. 
viii) Not only is an appropriate mixture of generic business strategies required but also the systematic support (such as additional technologies or facilities, substantial policy tools, and social infrastructure) through which manufacturers may achieve a sustainable new company-specific business model.

Key contribution of this study is identifying generic business strategies through life cycle approaches that conventional manufacturers can reference while developing company-specific sustainable business models. However, life cycle-based generic business strategies may not always offer manufacturers radical changes towards sustainability because not all generic business strategies that generate environmental benefits create profits or social benefits and vice versa. Hence, the performance of a mixture of generic business strategies should also be evaluated quantitatively when sustainable business models are being designed. Thus, future studies should focus on developing pre-evaluation methods for the sustainability of a mixture of generic business strategies in new business models.

\section{Acknowledgements}

This study was carried out as part of the "Development of Green Design Index" project of the Eco-product Research Institute at Ajou University and was financially supported by the Korea Institute of Industrial Technology of the Korean Ministry of Trade, Industry and Energy.

\section{References}

Bartolomeo, M., dal Maso, D., de Jong, P., Eder, P., Groenewegen, P., Hopkinson, P., James, P., ... Zaring, O. (2003). Eco-efficient producer services - what are they, how do they benefit customers and the environment and how likely are they to develop and be extensively utilized?. Journal of Cleaner Production, 11(8), 829-837. http://dx.doi.org/10.1016/S0959-6526(02)00157-9

Behrendt, S., Jasch, C., Kortmap, J., Hrauda, G., Pfitzner, R., \& Velte, D. (2003). Eco-service development: reinventing supply and demand in the European Union. Sheffield: Greenleaf.

Brezet, J. C., Bijma, A. S., Ehrenfeld, J., \& Silvester, S. (2001). The design of eco-efficient services: Method, tools and review of the case study based 'Designing Eco-efficient Services' project. Report for the Dutch Ministries of Environment (VROM). The Netherlands: Delft University of Technology.

Dyllick, T., \& Hockerts, K. (2002). Beyond the business case for corporate sustainability. Business Strategy and the Environment, 11(2), 130-141. http://dx.doi.org/10.1002/bse.323

Elkington, J. (1997). Cannibals with forks: the triple bottom line of $21^{\text {st }}$ century business. Oxford: Capstone.

Goedkoop, M. J., van Halen, C. J. G., te Riele, H. R. M., \& Rommens, P. J. M. (1999). Product service systems, ecological and economic basics. Report for Dutch Ministries of Environment (VROM) and Economic Affairs (EZ). Amersfoort, The Netherlands: PRé Consultants.

Green Car. (2011). The webpage of car sharing service in Korea. Retrieved September 30, 2012, from $\mathrm{http}: / / \mathrm{www} . g r e e n c a r . c o . k r /$

Halme, M., Jasch, C., \& Scharp, M. (2004). Sustainable homeservices? Toward household services that enhance ecological, social and economic sustainability. Ecological Economics, 51(1-2), 125-138. http://dx.doi.org/10.1016/j.ecolecon.2004.04.007

Kondoh, S., Kurakwa, K., Kato, S., Umeda, Y., \& Takata, S. (2006). Analysis of key success factors for eco-business through case studies in Japan. In 13th CIRP International conference on life cycle engineering, 31 May - 2 June, Leuven, Belgium.

Lovins, A. B., Lovins, L. H., \& Hawken, P. (2008). A Road Map for Natural Capitalism. Harvard Business Review on Profiting from Green Business (pp. 1-34). Boston: Harvard Business School Publishing. (Reprinted from Harvard Business Review, 77(3), 145-148, 1999).

Magretta, J. (2010). Why business models matter. Harvard Business Review on Business Model Innovation (pp. 1-17). Boston: Harvard Business School Publishing. (Reprinted from Harvard Business Review, 80(5), 86-92, 2002).

Manzini, E., Vezzoli, C., \& Clark, G. (2001). Product-service systems: using an existing concept as a new approach to sustainability. Journal of Design Research, 1(2). http://dx.doi.org/10.1504/JDR.2001.009811

Manzini, E., \& Vezzoli, C. (2003). A strategic design approach to develop sustainable product service systems: examples taken from the 'environmentally friendly innovation' Italian prize. Journal of Cleaner Production, 11(8), 851-857. http://dx.doi.org/10.1016/S0959-6526(02)00153-1 
Mont, O. (2000). Product Service-Systems, shifting corporate focus from selling products to selling product-services: a new approach to sustainable development. Stockholm, Swedish EPA, AFR-report 288: 83.

Mont, O. (2002). Clarifying the concept of product-service system. Journal of Cleaner Production, 10(3), 237-245. http://dx.doi.org/10.1016/S0959-6526(01)00039-7

Mont, O. (2004). Product-service systems: panacea or myth?. Ph.D dissertation. Sweden: IIIEE, University of Lund.

Mont, O., \& Plepys, A. (2004). What is behind meager attempts to sustainable consumption? Institutional and product-service system perspective. In International Workshop on Driving Forces of and Barriers to Sustainable Consumption, 5-6 March, Leeds, UK.

Nakamura, N., Mandai, K., Fukushige, S., \& Umeda, Y. (2012). Proposal of a methodology for supporting generation of new eco-business ideas. Design for Innovation Value Towards a Sustainable Society. Proceedings of EcoDesign 2011, 451-456. (In: 7th International Symposium on Environmentally Conscious Design and Inverse Manufacturing, 30 November - 2 December, Kyoto, Japan). http://dx.doi.org/10.1007/978-94-007-3010-6_86

NHN Corporation. (2011). The webpage of Nanum-ecofont. Retrieved September 30, 2012, from $\mathrm{http}: / /$ hangeul.naver.com/eco

Reinhardt, F. L. (2008). Bringing the Environment Down to Earth. Harvard Business Review on Profiting from Green Business (pp. 35-58). Boston: Harvard Business School Publishing. (Reprinted from Harvard Business Review, 77(4), 149-157, 1999).

Rothenberg, S. (2004, December). Selling small and smart: The future of the sustainable enterprise. A Research Monograph of the Printing Industry Center at RIT, A Joint Project with the International Motor Vehicle Program at MIT Working Paper No. PICRM-2004-01. http://dx.doi.org/10.2139/ssrn.908385

Rothenberg, S. (2007, January 1). Sustainability through Servicizing. MIT Sloan Management Review, 48(2), 83-91. Retrieved from http://sloanreview.mit.edu/article/sustainability-through-servicizing/

Seddon, P. B., \& Lewis, G. P. (2003). Strategy and Business Models: What's the Difference?. In 7th Pacific Asia Conference on Information Systems, 10-13 July, Adelaide, South Australia.

Tukker, A. (2004). Eight types of product-service system: eight ways to sustainability? Experiences from SusProNet. Business Strategy and the Environment, 13(4), 246-260. http://dx.doi.org/10.1002/bse.414

Tukker, A., \& Tischner, U. (2006a). Product Service as a research field: past, present and future. Reflections from a decade of research. Journal of Cleaner Production, 14(17), 1552-1556. http://dx.doi.org/10.1016/j.jclepro.2006.01.022

Tukker, A., \& Tischner, U. (2006b). New business for old Europe: product-service development, competitiveness and sustainability. Sheffield: Greenleaf.

Umeda, Y., Nishioka, T., Fukushige, S., Kondoh, S., \& Takata, S. (2008). Proposal of Idea Generation Support Methodology for Eco-Business. Manufacturing Systems and Technologies for the New Frontier. Proceedings of the $41^{\text {st }}$ CIRP conference, 501-506. (In: 41st CIRP international Conference on Manufacturing Systems, 26-28 May, Tokyo, Japan). http://dx.doi.org/10.1007/978-1-84800-267-8_103

US Environmental Protection Agency (EPA). (2009). Green servicizing for a more sustainable us economy: key concepts, tools and analyses to inform policy engagement. US EPA, Office of Resource Conservation and Recovery, Washington, D.C.20460, EPA530-R-09-006. Retrieved from http://www.epa.gov/wastes/conserve/tools/stewardship/docs/green-service.pdf

van Halen, C., Vezzoli, C., \& Wimmer, R. (2005). Methodology for product service innovation: How to implement clean, clever and competitive strategies in European industries. Assen, The Netherlands: Koninklijke van Gorcum.

Yip, G. S. (2004). Using strategy to change your business model. Business Strategy Review, 15(2), 17-24. http://dx.doi.org/10.1111/j.0955-6419.2004.00308.x

Zaring, O., Bartolomeo, M., Eder, P., Hopkinson, P., Groenewegen, P., James, P., ... Örninge, M. (2001). Creating eco-efficient producer services. Report of an EU project. Gothenburg: Gothenburg Research Institute. Retrieved from http://www.score-network.org/files/828_18.pdf 


\section{Copyrights}

Copyright for this article is retained by the author(s), with first publication rights granted to the journal.

This is an open-access article distributed under the terms and conditions of the Creative Commons Attribution license (http://creativecommons.org/licenses/by/3.0/). 